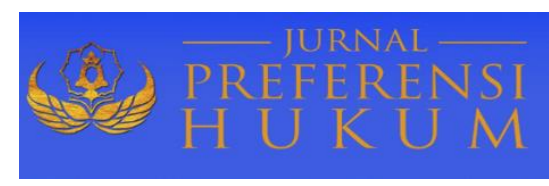

Jurnal Preferensi Hukum | ISSN: 2746-5039

Vol. 2, No. 1 - Februari 2021, Hal. 188-192| Available online at

https://www.ejournal.warmadewa.ac.id/index.php/juprehum

DOI: https://doi.org/10.22225/jph.2.1.3066.188-192

\title{
PEMBUNUHAN ANAK OLEH IBU KANDUNG YANG DI BAWAH UMUR
}

\author{
Putu Ayu Devi Laxsmi, I Ketut Sukadana, I Nyoman Sujana \\ Fakultas Hukum Universitas Warmadewa, Denpasar-Bali, Indonesia
}

\begin{abstract}
Abstrak
Berbagai macam peristiwa tindak pidana yang dilakukan oleh anak yang belum bisa mempertanggungjawabkan perbuatannya secara hukum. Undang - Undang Nomor 11 Tahun 2012 tentang sistem peradilan anak, yang artinya agar lebih memberikan perlindungan dan pengayoman terhadap anak untuk masa depannya yang masih panjang. Namun, selain anak sebagai korban tindak pidana tidak menutup kemungkinan anak juga dapat menjadi pelaku tindak pidana. Penelitian ini bertujuan untuk mengetahui pertimbangan hakim dalam menjatuhkan pidana terhadap anak yang melakukan tindak pidana pembunuhan dalam Putusan Nomor: 18/Pid.Sus.Anak/2016/PN. Dps, dan untuk mengetahui sanksi pidana yang dijatuhkan oleh hakim terhadap pelaku tindak pidana pembunuhan dalam Putusan Nomor: 18/Pid.Sus.Anak/2016/PN. Dps. Metode yang digunakan adalah penelitian normatif dengan menggunakan pendekatan masalah yakni pendekatan perundangundangan yang menganalisis Peraturan Perundang-Undangan serta menggunakan pendekatan secara konseptual yang menganalisis masalah dengan konsep hukum dari buku dan literature serta pendekatan kasus. Hasil penelitian menunjukan bahwa Hakim dalam mempertimbangkan perkara tindak pidana Nomor: 18/Pid.Sus.Anak/2016/PN. Dps, yangg dilakukan oleh terdakwa yakni karena pelaku tindak pidana masih di bawah umur, dan belum pernah melakukan perbuatan melanggar hukum sebelumnya serta berjanji untuk tidak mengulangi perbuatan pelanggaran hukum lainnya. Berdasarkan perkara pembunuhan anak sebagaimana yang dimaksud pada kasus Nomor: 18/Pid.Sus.Anak/2016/PN. Dps, tidak diberlakukannya sanksi pidana, melainkan diberlakukannya Diversi yang mengarah pada UU No. 11 tahun 2012 tentang sistem peradilan pidana anak dan pada ayat (2) huruf a dan b wajib diupayakan Diversi dengan syarat dan ketentuan Orang tua bersedia menjaga, membimbing serta mengawasi anak mereka, sehingga tidak akan mengulangi perbuatannya.
\end{abstract}

Kata Kunci: Peradilan Anak, Pertimbangan hakim, Diversi.

\begin{abstract}
Various kinds of criminal incidents committed by children who have not been able to be legally accountable for their actions. Law Number 11 of 2012 concerning the juvenile justice system, which means that it is to provide more protection and protection for children for their long future. However, in addition to children being victims of criminal acts, it is possible that children can also become perpetrators of criminal acts. This study aims to determine the judge's consideration in imposing crimes against children who commit the crime of murder in Decision Number: 18 / Pid.Sus.Anak / 2016 / PN. Dps, and to find out the criminal sanctions imposed by the judge against the perpetrators of murder in Decision Number: 18 / Pid.Sus.Anak / 2016 / PN. Dps. The method used is normative research using a problem approach, namely a statutory approach that analyzes the Laws and Regulations and uses a conceptual approach that analyzes problems with legal concepts from books and literature as well as a case approach. The results showed that the Judge in considering a criminal case Number: 18 / Pid.Sus.Anak/2016 / PN. Dps, which was committed by the defendant, namely because the perpetrator of the criminal act was still a minor, and had never committed an illegal act before and promised not to repeat any other violation of the law. Based on the child murder case as referred to in case Number: $18 /$ Pid.Sus.Anak / 2016 / PN. Dps, the imposition of criminal sanctions, but the enactment of Diversion which leads to Law no. 11 of 2012 concerning the juvenile criminal justice system and in paragraph (2) letters a and b, it is mandatory for Diversion to seek the terms and conditions. Parents are willing to look after, guide and supervise their children, so that they will not repeat their actions.
\end{abstract}

Keywords: Juvenile Justice, Judge's Consideration, Diversion.

\section{PENDAHULUAN}

Suatu fenomena pembunuhan anak dengan beragam jenis perkara kini membangkitkan topik hangat pada masyarakat. Banyak hal yang mendasari terjadinya perkara atau kasus terhadap anak sejauh ini, yang meliputi yakni anak dijadikan sebagai korban, menghindari masalah ekonomi, membatasi jumlah anak, menghindari kelahiran cacat, atau untuk menutupi malu dan lain sebagainya. Negara Indonesia yang berdasarkan Asas Pancasila dan Undang-Undang Dasar Negara Republik Indonesia Tahun 1945, 
yang setiap tingkah laku Warga Negaranya tidak terlepas dari segala peraturan-peraturan yang bersumber dari hukum. Semua masyarakat wajib mengikuti aturan yang dilarang oleh undangundang seperti membunuhan, menculikan, berbuat cabul dan lain sebagainya (Sudarsono, 1991:33). Aturan dan undang-undang dibuat agar masyarakat mentaati sehingga menciptakan keadaan yang aman dan tentram serta jauh dari segala masalah sosial.

Pembunuhan tidak menutup kemungkinan di lakukan oleh orang-orang terdekatnya, keluarga, teman atau bahkan Ibu kandungnya sendiri, pembunuhan juga tidak tanggung-tanggung dilakukan oleh mereka yang belum bisa mempertanggungjawabkan perbuatannya secara hukum di karenakan mereka masih di bawah umur, suatu perbuatan melanggar hukum yang dilakukan oleh anak yang belum bisa mempertanggung jawabkan perbuatannya adalah tindakan dari kenakalan remaja, perbuatan kenakalan remaja ialah suatu tindakan yang di akibat karena kurangnya penerapan norma agama serta kurangnya perhatian orang tua dalam kehidupan bermasyarakat (Asyari, 1999:89). Berikut ini adalah beberapa penelitian yang terkait isu saat ini mengenai pembunuhan terhadap anak, yakni Cavanagh, Dobash, \& Dobash (2007); Ciani \& Fontanesi (2012); Pnevmatikos (2018); Terranova, Zen, Maguolo, Cirillo, \& Montisci (2018).

Dari berbagai fenomena tersebut perbuatan kenakalan remaja tidak hanya timbul dari dalam diri seseorang namun juga pengaruh dari orang-orang salah yang sering mereka jumpai yang pada usia mereka masih memiliki rasa keingintahuan yang sangat tinggi, mulai dari mengetahui, mencoba dan pada akhirnya berbuat. Salah satu dari bentuk kenakalan remaja disini yakni mereka yang belum cukup umur untuk melakukan perbuatan Dewasa yang jauh diatas batas umur mereka mulai dari keingintahuan, rasa cinta yang pertama kali mereka alami, rasa sayang yang masih hangat hingga suatu keingintahuan yang ingin di ketahui atau coba, sehingga mereka tidak control diri dengan sekali mencoba dan merasakan dapat membuat ketergantungan yang selalu ingin dilakukan hingga pada akhirnya aib dalam keluargapun muncul dengan disertai rasa penyesalan, ketakutan, dan ketidaksiapan diri, kini kekacauan pikiran yang kerap menyelimuti mereka hingga perbuatan di luar akal sehatpun mereka lakukan di luar kendali mereka, maka dari itu Tindak Pidana Pembunuhan dari aib yang mereka pebuat sendiri kini justru mendatangakan masalah baru bagi mereka yang melakukannya yakni Sanksi yang harus mereka terima dari perbuatannya sendiri (Walgito, 1982). Dalam Kitab Hukum Pidana Buku II Pasal 338 menjelaskan tindak pidana yang diperbuat anak berbunyi, "Barang siapa yang sengaja membunuh atau merampas nyawa orang lain diancam dengan pidana penjara paling lama 15 tahun, akan tetapi apabila yang melakukannya anak dibawah umur maka hukumannya separuh dari itu" (Moeljatno, 2011).

Perbedaan perlakuan dan ancaman yang diatur dalam Undang-UndangNomor 11 Tahun 2012 tentang Sistem Peradilan Anak, ini dimaksudkan untuk lebih memberikan perlindungan dan pengayoman terhadap anak dalam menyongsong masa depannya yang masih panjang. Adanya perihal sengaja atau tidaknya pada suatu perkara tersebut, pasti dinamakan perbuatan pelanggaran hukum. Dan pada tindakan pelanggaran itu telah terjadi kini hanya sanksi dan penyesalanlah yang harus di terima, mereka yang melakukan tindak pelanggaran hukum itu sadar bahwa suatu tindakan dilakukan merupakan tindakan melanggar hukum terlebih tindakan tersebut dilakukan oleh ibu kandungnya terlebih yang melakukan perbuatan tersebut adalah seorang anak yang belum bisa mempertanggung jawabkan perbuatannya secara hukum.

Anak merupakan generasi yang dilahirkan dari suatu hubungan dari perempuan dan laki-laki yang tidak menutup kemungkinana jika yang dilahirkan belum pernah melakukan perkawinan akan dinamakan seorang anak, anak adalah generasi bangsa, yang merupakan sumber daya manusia bagi pengembangan bangsa (Gultom, 2008:39). Undang-Undang Nomor 11 Tahun 2012 tentang sistem peradilan SPPA menjelaskan pengertian anak yang berhadapan dengan hukum ialah anak dalam perkara telah berumur 8 tahun, dan belum berumur 18 tahun serta tidak pernah malakukan perkawinan. Anak yang berhadapan pada hukum adalah anak yang telah mencapai usia 12 tahun tetapi belum mencapai usia 18 tahun dan belum menikah akan tetapi anak tersebut dapat dihadapkan dengan hukum apabila: dapat ditetapkan sebagai tersangka pada perkara, serta dapat juga menjadi sasaran tindak pidana jika melihat dan atau mendengar sendiri terjadinya suatu tindak pidana.

Berdasarkan fenomena tersebut penelitian ini bertujuan untuk menganalisis pertimbangan hakim untuk menetapkan sanksi pada pelaku tindak pembunuhan oleh ibu kandung yang belum bisa mempertanggung jawabkan perbuatannya, dan menganalisis bentuk sanksi pidana yang dijatuhkan 
oleh hakim kepada pelaku tindak pembunuhan anak yang dilakukan ibu kandung yang belum bisa mempertanggung jawabkan perbuatannya secara hukum.

\section{METODE PENELITIAN}

Penelitian ini menggunakan pelenitian hukum normatif yaitu suatu prosedur ilmiah untuk menemukan kebenaran logika keilmuan hukum dari sisi normatifnya (Soekanto \& Mamudji, 2018). Pendekatan masalah yang digunakan dalam penulisan ini ialah pendekatan perundang-undangan dan pasal-pasal serta doktrin atau pandangan dari para ahli yang berkaitan dengan masalah yang dihadapi terpaut dengan diversi dan narkotika pada anak. Sumber bahan hukum yang digunakan yaitu sumber bahan hukum primer berupa peraturan perundang-undangan yang mengatur tentang dan narkotika serta bahan hukum sekunder yang berupa buku-buku, jurnal ilmiah, laporan ilmiah dan karya ilmiah lainnya yang berhubungan dengan masalah yang sedang diteliti. Pengumpulan bahan hukum dengan cara mencatat, mengutip berdasarkan perundang-undangan yang terkait dengan permasalahan yang sedang diteliti. Setelah semuanya data terkumpul selanjutnya dianalisis secara deskritif.

\section{HASIL DAN PEMBAHASAN}

\section{Pertimbangan Hakim dalam Menjatuhkan Pidana terhadap Anak yang Melakukan Tindak Pidana Pembunuhan}

Dalam hal membuat suatu putusan, seorang hakim wajib mempertimbangkan beberap hal, seperti umur. Umur merupakan penilaian hakim untuk memutus suatu perkara. Apabila umur terdakwa dibawah umur, maka penjatuhan hukumnya tidak sama dengan orang dewasa. Apabila terdakwa masih kanak-kanak pada penetapan pasal 1 ayat 1 undang-undang republik indonesia Nomor 11 Tahun 2012 tentang SPPA yaitu kanak merupakan orang dalam pekara anak nakal telah berumur 8tahun tetapi belum ber umur 18tahun dan tidak kawin, maka penjatuhan hukumannya adalah $1 / 2$ dari maks penjatuhan sanksi orang dewasa, terpenuhinya unsur tersebut hakim akan memperhitungkan terdakwa sudah memenuhi semua atau setengah dari unsur perkara pembunuhan yang dilakukan oleh anak tersebut (Bawengan, 2012:27). Unsur-unsur tindak pidana dalam perkara tersebut merupakan unsur yang terdapat dalam Pasal 6880 ayat (3) JO. Pasal 76 C Undang-Undang Nomor 35 Tahun 2014 tentang perubahan atas Undang - Undang Nomor 23 Tahun 2002 tentang perlindungan kanak, dengan unsur sebagai berikut:

a) Setiap orang;

b) Menempatkan, membiarkan, melakukan, menyuruh melakukan, atau turut serta melakukan kekerasan terhadap Anak;

c) Mengakibatkan Anak mati;

Dan hakim dapat menjatuhkan hukuman terhadap terdakwa yang melakukan tindakan melawan hukum (Bawengan, 2012). Disertai adanya alat bukti yang Sah di ajukan dalam sidang, sesuai dengan penetapan pasal 184 KUHP, suatu bukti yang Sah yakni terdiri atas keterangan saksi, keterangan ahlii, adanya surat, adanya petunjuk, dan keterangan dari terdakwa. Dari salah satu alat bukti itu min 2 alat bukti yang di gunakan, selain itu hakim harus memiliki keyakinan untuk dasar memperhitungkan dalam memutuskan hukuman kepada terdakwa. Keyakinan ini di peroleh dari fakta-fakta yang terjadi di dalam sidang, apabila hakim tidak yakin pada perkara yang dilakukan oleh kanak maka hakim dapat menjatuhkan putusan seringan-ringanya hingga putusan bebas, hakim juga memperhitungkan hal-hal yang memberatakan dan meringankan terdakwa. Pertimbangan ini di buat hakim untuk mencapai suatu keadilan untuk terdakwa, korban atau keluarga korban, serta masyarakat. Hal-hal yang tersebut dapat dilihat dari perilaku terdakwa yang mencemaskan orang sekitar, perilaku terdakwa yang membuat trauma terhadap korban atau keluarga korban, terdakwa bersikap baik dalam persidangan, terdakwa tidak pernah dihukum sebelumnya.Hasil paparan yang dibuat oleh balai pemasyarakatan, yang meliputi, faktor intern yaitu di dalam diri terdakwa dalam perkara ini contohnya pada mental terdakwa apakah benar mempunyai sifat bawaan atau kepribadian ganda yang dapat merugikan kehidupan sosial masyarakat sehingga pelaku wajib di pisahkan dari masyarakat agar mendaptakan perhatian, pembinaan, pengawasan dan pendidikan yang khusus agar menjadi pribadi yang lebih baik, faktor ekstern adalah faktor dari luar yang mempengaruhi pelaku yang $\mathrm{d}$ iperoleh dari lingkungan, keluarga, pergaulan dan pendidikan sehingga menimbulkan akibat bagi korban, masyarakat, orang tua dan lingkungan. Uraian dari ortu atau wali dalam persidangan sangat penting, keterangan tersebut di adakan dalam persidangan untuk mendampingi perkara anak masih di 
bawah umur sehingga masih menjadi tanggung jawab sepenuhnya bagi ortu, karena kesehariannya bersama terdakwa lebih memahami kebiasaan terdakwa, sehingga dapat memberikan keterangan yang akan menjadi perhitungan untuk hakim dalam menjatuhkan sanksi pidana yang dilakukan oleh anak. konsekwensi bagi korban dan keluarga dapat di lihat dari perbuatan yang ditimbulkan oleh terdakwa, seperti terjadi troma atau penyesalan yang dalam hingga setress pada keluarga korban dari tindak pidana yang di perbuat oleh terdakwa terhadap korban. Berdasarkan pertimbangan hakim tersebut diatas maka dalam perkara pembunuhan anak sebagaimana yang dimaksud dalam perkara No:18/Pid.Sus.Anak/2016/PN.Dps. Menimbang, bahwa laporan Hakim pada tanggal 18 Juli 2016 antara Anak dan Penyidik atau Penuntut Umum telah dicapai kesepakatan Diversi.

Pertimbangan, dari sepakatnya melakukan Diversi kini sudah memenuhi syarat dan tidak menentang peraturan per undang - undangan sehingga harus di kabulkan. Dalam Undang-Undang pasal 28 Nomor. 4 tahun 2004 tentang Kekuasaan Kehakiman, yang menjelaskan, hakim wajib menggali, mengikuti, dan memahami nilai-nilai hukum dan rasa keadilan yang hidup dalam masyarakat, dan hakim wajib untuk mempertimbangkan berat-ringan nya sanksi dalam melihat sifat baik dan buruk dari terdakwa, serta konsekwensi yang ditimbulkan dari perbuatan tersebut terhadap keluarga korban dan masyakarat (Siregar, 2007:19).

Penerapan sanksi pidana dalam pokok masalah perkara tersebut menurut undang-undang No. 11 Tahun 2012 tentang SPPA yakni telah menetapkan apa yang dimaksud anak yang berkonflik dengan hukum, Undang - Undang ini berlaku khususnya yang berkaitan dengan tindak pidana yang dilakukan oleh anak, dengan adanya undang - undang Nomor 11 tahun 2012 tentang SPPA, telah menjadi acuan dalam perumusan konsep KUHP tahun 2012 berhubungan dengan pidana dan tindak pidana bagi anak (Prinst, 2013:43). Dengan demikian, tidak akan ada tumpang tindih atau saling bertentangan. Undang - undang Nomor 11 tahun 2012 tentang SPPA, menyatakan bahwa kanak yang berperkara akan disebut anak apabila anak yang telah berumur 12tahun, tetapi belum ber umur 18 tahun yang diduga melakukan tindak pidana, yang dimaksud anak yang berperkara dengan hukum adalah anak yang melakukan tindak pidana, atau anak yang melakukan perbuatan pelanggaran dalam peraturan per undang - undangan atau aturan hukum lain yang berlaku dalam masyarakat yang tersebut (Bawengan, 2012:27). Jika di gabungkan dengan Undang - Undang Nomor 12 Tahun 1995 tentang Pemasyarakatan maka kondisi kanak nakal tersebut dalam putusan pengadilan di sebut sebagai Anak Pidana atau Anak Negara. Disebut Anak Pidana ialah anak yang terpidana di LP paling lama sampai ber umur 18 tahun, dan di sebut sebagai Anak Negara ialah anak yang di serahkan pada negara untuk dididik dan ditempatkan di LP paling lama sampai ber umur 18tahun. Berdasarkan ketentuan Undang - undang Nomor 11 Tahun 2012 tentang Sistem Peradilan Pidana Anak, anak yang ber konflik dengan hukum dapat dijatuhkan pidana pokok dan pidana tambahan. Sesuai dalam Pasal 71 ayat (1) dan ayat (2) Undang - undang Nomor 11 tahun 2012 tentang Sistem Peradilan Pidana Anak, yang mengatur tentang anak yang berkonflik dengan hukum.

Dari penjelasan pada permasalahan yang timbul maka tujuan penelitian dalam permasalahan tersebut secara umum yaitu untuk memberi pemahaman diri sebagai usaha menyampaikan pikiran dan pendapat secara tertulis dan agar dapat memperoleh Gelar Sarjana Hukum guna dapat melaksanakan Tri Dharma Perguruan Tinggi dan dapat memberikan sumbangan pikiran maupun pengetahuan dalam bidang ilmu hukum khususnya berkaitan dengan perlindungan anak adapun tujuan secara khusus dalam permasalahan ini yaitu untuk mengetahui pertimbangan hakim dalam menjatuhkan pidana terhadap pelaku pembunuhan anak oleh ibu kandung di bawah umur dan bagaimana penjatuhan hukum dari hakim terhadap pelaku perkara oleh anak tersebut. Berdasarkan beberapa poko permasalahan yang timbul maka penelitian ini menggunakan metode penelitian Hukum Normatif sebagaimana pengkajiannya dilakukan melalui studi kepustakaan yaitu, berupa pengumpulan bahan bahan hukum dan menggunakan pendekatan masalah yakni pendekatan perundang - undangan, yang berlaku dan berkaitan dengan permasalahan yang dibahas, selain itu juga menggunakan pendekatan secara konseptual yang menganalisis permasalahan melalui konsep - konsep hukum yang diambil dari buku - buku dan literatur - literatur yang ada relevasinya dengan permasalahan, selain itu penelitian ini juga menggunakan pendekatan kasus (Marzuki, 2006).

Dalam kasus perkara tindak pidana No:18/Pid.Sus.Anak/2016/PN. Dps, ,yang dilakukan oleh anak yakni Hakim memberi pertimbangan karena pelaku tindak pidana masih di bawah umur, selain itu belum pernah melakukan perbuatan melanggar hukum sebelumnya serta berjanji untuk tidak mengulangi perbuatan pelanggaran hukum lainnya, dalam kasus ini hakim akan tertuju pada Undang- 
Undang Nomor. 11 Tahun 2012 tentang SPPA, maka hasil dari pertimbangan tersebut pelaku dikembalikan kepada orang tua atau wali untuk dibimbing dan mengawasi sang anak agar tidak mengulangi perbuatan - perbuatan melanggar hukum lagi. Dan Hasil dalam dalam perkara No:18/Pid.Sus.Anak/2016/PN.Dps, Sanksi Pidana yang dijatuhkan terhadap terdakwa yakni tidak diberlakukannya Sanksi Pidana melainkan diberlakukannya Diversii dengan syarat dan ketentuan orang tua bersedia menjaga, membimbing serta mengawasi anak mereka sehingga tidak akan mengulangi perbuatannya, serta anak berjanji untuk memperbaiki sikap dan perilakunya untuk tidak mengulangi perbuatannya dengan limit waktu 6 bulan terhitung sejak ditetapkan, apabila anak mengulangi lagi maka anak bersedia diproses secara hukum yang berlaku.

\section{KESIMPULAN DAN SARAN}

\section{Simpulan}

Kesimpulan dari perkara tindak pidana Nomor:18/Pid.Sus.Anak/2016/PN. Dps, yang di sebabkan oleh kanak maka hakim mempertimbangkan beberapa hal yaitu karena pelaku tindak pidana masih di bawah umur, dan belum pernah melakukan perbuatan melanggar hukum sebelumnya serta berjanji untuk tidak mengulangi perbuatan pelanggaran hukum lainnya, serta hakim harus tertuju pada Undang-Undang Nomor. 11 Tahun 2012 tentang SPPA. Dan hakim tidak memberlakukan sanksi pidana melainkan diberlakukannya Diversi dengan syarat dan ketentuan orang tua bersedia menjaga, membimbing serta mengawasi anak mereka sehingga tidak akan mengulangi perbuatannya, serta anak berjanji untuk memperbaiki sikap atau perilakunya untuk tidak mengulangi perbuatannya dengan limit waktu 6 bulan terhitung sejak ditetapkan, apabila anak mengulangi lagi maka anak bersedia diproses secara Hukum yang berlaku.

\section{Saran}

Hakim dalam membuat keputusan pada tindak pidana yang di lakukan oleh kanak harus berdasarkan pada keputusan norma dan bantuan hukum, dengan prinsip profesi nya juga harus memperhatikan faktor di luar bantuan hukum, baik dari segi kriminal, sosial dan psikogis juga hakim dituntut unutk mempertimbangkan dari segi filosofis dan kepada masyarakat agar lebih menjaga anak-anaknya serta memberikan bimbingan dan pemahaman yang tepat supaya anak-anaknya terhindar dari tindakan perbuatan melanggar hukum, kepada pemerintah diharapakan agar memberikan penyuluhan hukum kepada masyarakat sangatlah penting agar masyarakat dapat lebih mengerti dan taat hukum.

\section{DAFTAR PUSTAKA}

Asyari, S. I. (1999). Patologi Sosial. Surabaya: Usaha Nasional.

Bawengan, G. (2012). Penyidikan Perkara Pidana dan Teknik Introgasi. Jakarta: Pradya Paramita.

Cavanagh, K., Dobash, R. E., \& Dobash, R. P. (2007). The Murder of Children by Fathers in the Context of Child Abuse. Child Abuse \& Neglect, 31(July), 731-746.

Ciani, A. S. C., \& Fontanesi, L. (2012). Mothers Who Kill Their Offspring: Testing Evolutionary Hypothesis in a 110-Case Italian Sample. Child Abuse \& Neglect, 36(6), 519-527.

Gultom, M. (2008). Perlindungan Hukum terhadap Anak dalam Sistem Peradilan Pidana Anak di Indonesia. Bandung: Refika Aditama.

Marzuki, P. M. (2006). Penelitian Hukum (Ed. II). Jakarta: Kencana Prenada Media Group.

Moeljatno. (2011). KUHP Kitab Undang-Undang Hukum Pidana. Jakarta: Bumi Aksara.

Pnevmatikos, D. (2018). When Do Children Start to Take Mitigating Circumstances into Account when Judging the Act of Killing? Cognitive Development, 48(July), 94-104.

Prinst, D. (2013). Hukum Anak Indonesia. Bandung: Citra Aditya Bakti.

Siregar, M. (2007). Pedoman Praktis Melindungi Anak dengan Hukum Pada Situasi Emergensi dan Bencana Alam. Medan: Pusat kajian dan Perlindungan Anak (PKPA).

Soekanto, S., \& Mamudji, S. (2018). Penelitian Hukum Normatif: Suatu Tinjauan Singkat (18th ed.). Jakarta: Rajawali Pers.

Sudarsono. (1991). Kenakalan Remaja. Jakarta: Rineka Cipta.

Terranova, C., Zen, M., Maguolo, N., Cirillo, T., \& Montisci, M. (2018). Underage Victims and Perpetrators of Murder in Italy: 2007-2015. Journal of Forensic and Legal Medicine, 59(February), 39-44.

Walgito, B. (1982). Kenakalan Anak. Yogyakarta: Fakultas Pisikologi UGM.

Undang - Undang Dasar Negara Republik Indonesia Tahun 1945

Undang - Undang Nomor 11 Tahun 2012 Tentang Sistem Peradilan Pidana Anak

Undang - Undang Nomor 35 Tahun 2014 Tentang Perlindunagn Anak 